\title{
Kinerja Portofolio Saham pada Perusahaan Makanan, Properti dan Pertambangan di Bursa Efek Indonesia
}

\author{
Nasri Zarman \\ Sekolah Tinggi Ilmu Manajemen Indonesia Meulaboh \\ bangsnasri@gmail.com
}

\begin{abstract}
This research aimed to analyze the Portfolio's performance of food industry, property, and mining. There are three parameters, namely: Sharpe Performance, Traynor Performance, and Jensen Performance. The three performance measurements assume that there is a linear connection between the return portfolios with the return of some market index. During the period, 2009 to 2013, and the mining and gas sub-sector are more productive than the other sub-sectors. The mining sector is better than the Property Sector and the Food Sector. Then based on the method of Jensen ALPHA it showed the highest performance group of mining stocks, in proportion to the risk which is also very high. The study suggests that the existing has to be maintained and further improved so that the mission to develop sources of potential energy into a profitable investment portfolio can sustain.
\end{abstract}

Keywords: portofolio performance, stock, financial investment

\begin{abstract}
Abstrak
Tujuan penelitian ini adalah untuk mengetahui bagaimana kinerja Portofolio Saham pada Perusahaan Makanan, Properti dan Pertambangan di Bursa Efek Indonesia. Penelitian ini menggunakan 3 parameter yaitu; Kinerja Sharpe, Kinerja Traynor dan Kinerja Jensen. Ketiga pengukuran kinerja tersebut mengasumsikan adanya hubungan linear antara pengembalian (return) portofolio dengan pengembalian dari beberapa indeks pasar. Selama periode 20092013, dan sub sektor pertambangan dan gas yang paling tinggi hasilnya dibandingkan sub sektor yang lain, sektor pertambangan lebih baik dari Sektor Property dan Sektor Makanan, kemudian ditinjau dari Metode Jensen ALPHA menunjukkan kinerja yang tertinggi yaitu kelompok saham sektor pertambangan, sebanding dengan risikonya juga sangat tinggi. Saran dalam penelitian ini, sebaiknya kinerja yang telah ada dipertahankan dan lebih ditingkatkan sehingga misi untuk mengembangkan sumber-sumber energi potensial menjadi portofolio investasi yang menguntungkan terus berlanjut.
\end{abstract}

Keywords: kinerja portofolio, saham, investasi keuangan

Diterima: 17 Februari 2017; Direvisi: 25 April 2017; Disetujui: 10 Mei 2017 


\section{PENDAHULUAN}

Ketika kita melakukan investasi keuangan, untuk menghindari kerugian maka tempatkanlah dana tersebut pada berbagai instrumen investasi, seperti saham, obligasi, deposito, properti, permata dan logam mulia, perhiasan, lukisan, dan lain-lain. Gabungan dari berbagai instrumen investasi disebut sebagai portofolio. Hampir semua orang mempunyai portofolio investasi, baik yang terbentuk tanpa sengaja atau memang diputuskan melalui suatu perencanaan yang didukung dengan perhitungan dan pertimbangan rasional (Zubir, 2011). Seseorang melakukan investasi guna mendapatkan hasil yang maksimal untuk meningkatkan nilai kekayaan, tetapi dengan risiko sekecil mungkin. Memegang uang tunai mengandung biaya (opportunity cost) karena kehilangan kesempatan untuk mendapatkan hasil (return) bila uang tersebut diinvestasikan pada suatu usaha atau dibelikan instrumen investasi, disamping kemungkinan menurunnya daya beli dari uang tersebut akibat inflasi. Setiap investasi mempunyai karakteristik (hubungan return dan risiko) tertentu. secara umum kita mengatakan bahwa high-risk high-return, artinya hasil investasi yang tinggi mengandung risiko yang besar.

Karakteristik hubungan risiko dan return tersebut mulai dikembangkan Markowitz (1952). Artikel tersebut membuka pintu dimulainya teori portofolio modern. Markowitz (1952) mengatakan bahwa proses pemilihan portofolio dibagi atas dua tahap. Tahap pertama adalah mengobservasi sekuritas yang akan dipilih. Tahap kedua adalah memilih sekuritas yang akan dimasukkan dalam portofolio yang dilandasi oleh keyakinan terhadap kinerja sekuritas tersebut dimasa yang akan datang. Markowitz menekankan bahwa investor menganalisis dan memilih sekuritas berdasarkan expected return dan varians return sekuritas tersebut.

Karena tidak tahu apa yang akan terjadi di masa yang akan datang, orang hanya bisa menduga return suatu sekuritas dan penyimpangannya berdasarkan data masa lalu. Markowitz mengatakan bahwa investor dapat memaksimumkan expected return melalui diversifikasi sekuritas dalam portofolio karena saham-saham dalam portofolio saling berkorelasi. Sesuai dengan hukum "large of number", makin banyak sekuritas dalam portofolio, maka actual return portofolio tersebut akan mendekati expected return dan variannya makin kecil. Lebih lanjut Markowitz mengatakan bahwa diversifikasi tidak dapat menghilangkan semua varians return sekuritas 
dalam portofolio dan portofolio yang mempunyai expected return maksimum tidak selamanya mempunyai varians minimum. Portofolio investor adalah yang memberikan expected return maksimum pada varian tertentu, atau portofolio dengan varians terkecil pada expected return tertentu.

Teori Markowitz tersebut mengimplikasikan bahwa untuk dapat menerima risiko yang lebih besar, investor harus di kompensasi dengan kesempatan untuk dapat menerima resiko yang lebih besar, investor harus dikompensasi dengan kesempatan untuk mendapatkan return yang besar juga. Seperti tampak pada formula varians portofolio, hubungan return dan risiko portofolio tidak selamanya linear, tetapi berupa parabola. Pilihan investasi yang rasional terletak di wilayah yang mendukung hubungan high risk high return.

Portofolio saham adalah investasi yang terdiri dari berbagai saham perusahaan yang berbeda dengan harapan bila harga salah satu saham menurun, sementara yang lain meningkat, maka investasi tersebut tidak mengalami kerugian. Selain itu, korelasi antara return satu saham dan saham lainnya juga memperkecil varians return portofolio tersebut. Saham adalah sertifikat bukti kepemilikan sebuah perusahaan. Pemilik saham berhak atas laba perusahaan yang disebut sebagai deviden dan juga menanggung resiko bila perusahaan merugi. Saham yang dimaksud dalam investasi adalah saham biasa (common stock) yang diperdagangkan dibursa, khususnya Bursa Efek Indonesia (Zubir, 2011).

Volatilitas yang terjadi pada investasi saham disebabkan karena terjadinya pola bearish dan bulish pada pasar modal. Usman (2016) membuktikan bahwa terdapat 61 indikasi pola bearish (38.85\%) dan 96 kali indikasi terjadinya pola bulish pada indeks harga saham gabungan. Volatilitas akan dapat memengaruhi volume perdagangan pada pasar modal (Sutrisno, 2017).

Dalam mengalokasikan dana untuk setiap saham dalam portofolio, Warrent Buffet (Zubir, 2011) seorang investor terkenal mengatakan bahwa "jika anda menemukan saham yang tepat, mengapa harus membeli sedikit, Investasikanlah uang anda sebanyak-banyaknya dalam saham tersebut." Saran yang disampaikan oleh Warrent Buffet tersebut dilandasi oleh analisis fundamental (jangka panjang) yang baik terhadap perusahaan yang mengeluarkan saham tersebut. Saham yang 
dipilih adalah saham perusahaan yang diperkirakan mempunyai prospek yang baik di masa mendatang. Warrent Buffet memilih saham karena nilai, yaitu memilih saham-saham perusahaan dengan kriteria sebagai berikut: (1) Bisnis perusahaan tersebut dapat dimengerti. (2) Prospek jangka panjang yang menguntungkan. (3) Dijalankan oleh orang-orang yang jujur dan kompeten. (4) Bisnis yang harganya sangat menarik.

Terlepas dari cara orang yang memilih saham yang akan dimasukkan kedalam portofolio, teori portofolio menjelaskan bahwa risiko portofolio lebih rendah dari pada risiko saham individu dalam portofolio tersebut karena varians return saham sebagai ukuran resiko investasi tersebut saling meredam. Oleh karena itu, untuk menurunkan resiko, jangan hanya menginvestasikan uang pada satu jenis instrumen saja. Kombinasi saham apa pun dalam portofolio akan memberikan resiko yang lebih kecil dari pada risiko masing-masing saham, tetapi apakah sahamsaham yang dipilih mempunyai prospek yang baik, jawabannya belum tentu. Jika kita hanya menggunakan data masa lalu dan menekankan pada pendekatan matematis dalam menentukan jenis dan proporsi saham dalam portofolio, sahamsaham yang dipilih belum tentu mempunyai prospek yang baik dan hasilnya jauh dari yang dibayangkan.

Diversifikasi investasi merupakan salah satu strategi untuk menurunkan risiko dalam arti investor menanamkan uangnya pada berbagai instrumen investasi. Namun, Warrent Buffet mengatakan bahwa diversifikasi sesungguhnya bukanlah strategi yang tepat dalam berinvestasi. Buffet menekankan konsentrasi investasi pada beberapa saham saja. Perbedaan yang mendasar antara srategi diversifikasi dan konsentrasi investasi terletak pada proses pemilihan saham-saham yang akan dimasukkan ke dalam portofolio. Strategi diversifikasi dalam hal ini adalah melakukan investasi pada banyak saham dengan maksud hanya untuk mengamankan investasi tanpa didasari oleh analisis fundamental perusahaannya. Sementara itu, strategi konsentrasi Buffet dilandasi oleh analisis fundamental jangka panjang yang sangat kuat dan melibatkan suasana hati dan emosi dalam memilih saham yang akan dibeli.

Masalah dalam penelitian ini yang terindifikasi oleh peneliti diantaranya: 
(1) Bahwa seorang investor dalam menanamkan modalnya selalu melihat keuntungan/Pendapatan (Return) dan Resiko (risk) dari setiap dana yang diinvestasikannya, karena kedua hal tersebut merupakan faktor penting dalam menilai kinerja suatu portofolio. (2) Return saham yang rendah mendorong kinerja yang kurang baik. (3) Dalam menyikapi resiko setiap investor berbeda-beda pandangan yang dikelompokkan menjadi 3 (tiga), yaitu sikap yang menyukai resiko (risk seeker), sikap yang netral terhadap resiko (risk neutral) dan sikap yang tidak menyukai resiko (resiko averse), sehingga setiap investor mempunyai preferensi yang berbeda dalam melihat resiko untuk menilai kinerja suatu portofolio, yaitu dengan melihat resiko total dan ada yang hanya melihat pada resiko sistematis atau beta.

Tujuan dari penelitian ini adalah: (1) Untuk menentukan saham yang termasuk kedalam portofolio optimal dari perusahaan makanan dan minuman, property dan real estate, serta pertambangan minyak. (2) Untuk menentukan kelayakan apakah portofolio saham dari ketiga kelompok sektor tersebut, yang manakah yang layak untuk di investasikan.

\section{METODE}

Pendekatan yang digunakan untuk memperoleh gambaran efisiensi portofolio saham dalam penelitian ini menggunakan pendekatan kuantitatif. Demikian pula dengan analisis kinerja portofolio saham, dengan return saham pada perusahaan makanan dan minuman, property dan realestate dan pertambangan minyak di Bursa Efek Indonesia dengan pendekatan kuantitatif. Pembahasan analisisnya digunakan pendekatan deskriptif analisis.

Pengukuran kinerja portofolio (tingkat kemampuan suatu portfolio untuk memberikan hasil sesuai dengan risiko. Metode analisa data yang digunakan dalam penelitian ini analisa kualitatif, yang digunakan untuk menganalisa ukuran kinerja portofolio yang terdiri atas: (1) Portofolio kelompok saham sektor industri barang konsumsi, sub sektor Makanan dan Minuman yang termasuk dalam LQ45. (2) Portofolio kelompok saham sektor property, sub sektor Property dan Realestate yang termasuk dalam LQ45.

Pengukuran kinerja portfolio saham akan menggunakan metode Sharpe, 
metode Treynor, dan metode Jensen.

\section{Metode Sharpe}

Mengukur kinerja portofolio menggunakan metode Sharpe, dengan rumus :

$$
S_{P}=\frac{R_{P}-R_{f}}{\sigma_{P}}
$$

Dimana:

$S_{P}=$ indek kinerja Sharpe.

$R_{P}=$ return portofolio atau tingkat pengembalian pasar pada periode $\mathrm{t}$.

$R_{f}=$ return bebas risiko tingkat bunga bebas risiko pada periode $\mathrm{t}$.

$\sigma_{P}=$ total risiko yaitu hasil jumlah dari risiko sistematik dan risiko unsistematik (deviasi standar)

Jika nilai RVAR positif dan semakin besar maka kinerja portofolio semakin baik.

\section{Metode Treynor}

Mengukur kinerja portofolio menggunakan metode Treynor, dengan rumus :

$$
\mathrm{T}_{P}=\frac{R_{P}-R_{f}}{\beta_{P}}
$$

Dimana:

$\mathrm{T}_{P}=$ indek kinerja Treynor.

$R_{P}=$ return Portofolio atau tingkat pengembalian pasar pada periode $\mathrm{t}$.

$R_{f}=$ return bebas risiko tingkat bunga bebas risiko pada periode $\mathrm{t}$.

$\beta_{P}=$ risiko pasar dari portofolio atau risiko sistematik portofolio (koefisien beta pasar).

\section{Metode Jensen}

Mengukur kinerja portofolio menggunakan metode Jensen, dengan Rumus :

$$
a_{P}=R_{P}-\left\lfloor R_{i}+b_{P}\left(R_{m}-R_{f}\right)\right\rfloor
$$

Keterangan :

$a_{P}=$ indek jansen

$R_{P}=$ return portofolio pada periode- $\mathrm{t}$

$R_{f}=$ return pada investasi bebas risiko pada periode- $\mathrm{t}$ 


\section{HASIL DAN PEMBAHASAN}

Bursa Efek Indonesia memeperkenalkan indeks baru kepada para pelaku pasar dan investor modal dipasar modal untuk memantau kecenderungan pasar. Nama indeks tersebut adalah LQ45. Sesuai namanya maka perhitungan indeks ini didasarkan pada nilai pasar 45 saham pilihan yang terseleksi setiap 6 bulan sekali. Berdasarkan seleksi tersebut selama 5 tahun yaitu dari tahun 2009 sampai 2013 diperoleh saham yang secara konsisten tercatat sebagai indeks LQ45. Pertama, adalah saham hasil perhitungan kinerja portofolio yang terdiri dari 3 (tiga) kelompok saham yang terdaftar pada BEI ( Bursa Efek Indonesia ). Kedua, Hasil Perhitungan Portofolio dari 3 Kelompok Saham, Hasil pengelolaan data portofolio yang terdiri dari saham-saham yang terdaftar pada BEI ( Bursa Efek Indonesia ) dengan data 5 tahun. Ketiga, Portofolio 3 Kelompok Saham, Hasil perhitungan untuk Sharpe (RVAR), Treynor (RVOL) dan Jensen (ALPHA) adalah :

Perusahaan yang bergerak dalam usaha Sektor Industri Barang Konsumsi yaitu Sub Sektor Makanan dan Minuman yang termasuk dalam LQ45 adalah PT. Indofood CBP Sukses Makmur Tbk dan PT. Indofood Sukses Makmur Tbk, ada 7 perusahaan yang bergerak dalam Sektor Property dan Realestate yang termasuk dalam LQ45. Sedangkan di sektor Pertambangan yaitu sub sektor Pertambangan Minyak dan Gas adalah PT. Elnusa Tbk, PT. Energi Mega Persada Tbk, PT. Medco Energi Internasional Tbk dan PT. Bumi Resources Tbk.

Tabel 1. Return Ekspektasi Pasar

\begin{tabular}{cccc}
\hline Tahun & $\begin{array}{c}\text { Sektor Makanan \& } \\
\text { Minuman }\end{array}$ & $\begin{array}{c}\text { Sektor Properti \& Real } \\
\text { Estate }\end{array}$ & $\begin{array}{c}\text { Sektor Minyak \& } \\
\text { Gas }\end{array}$ \\
\hline 2009 & $0.89 \%$ & $-5.11 \%$ & $3.62 \%$ \\
2010 & $2.14 \%$ & $0.89 \%$ & $95.07 \%$ \\
2011 & $2.34 \%$ & $-0.02 \%$ & $125.16 \%$ \\
2012 & $1.76 \%$ & $0.45 \%$ & $17.01 \%$ \\
2013 & $0.74 \%$ & $0.91 \%$ & $26 \%$ \\
\hline
\end{tabular}

Pengukuran menggunakan metode Sharpe atau juga disebut sebagai Reward to Variability Rasio (RVAR) menekankan pada risiko total atau deviasi standar. Deviasi Standar menunjukkan besar kecilnya perubahan return suatu saham terhadap return rata-rata saham yang bersangkutan. Untuk kepentingan memprediksi kinerja masa datang digunakan data masa lalu. Return rata-rata masa 
lalu dianggap sebagai return prediksi masa datang dan deviasi standar return masa lalu dianggap sebagai risiko masa datang.

Dari hasil perhitungan deviasi standar (dapat dilihat dalam lampiran) periode tahun 2009 sampai dengan tahun 2013. Return Ekspektasi pasar adalah 2.12 $\%$ (0.0212) perbulan, maka return ekspektasi portofolio [E(Rp) ] dapat dilihat pada Tabel 1.

Tabel 2. Varian Portfolio

\begin{tabular}{cccc}
\hline Tahun & $\begin{array}{c}\text { Sektor Makanan \& } \\
\text { Minuman }\end{array}$ & $\begin{array}{c}\text { Sektor Properti \& Real } \\
\text { Estate }\end{array}$ & $\begin{array}{c}\text { Sektor Minyak \& } \\
\text { Gas }\end{array}$ \\
\hline 2009 & 0.3826 & 0.4890 & 0.4060 \\
2010 & 0.3625 & 0.2449 & 3.7931 \\
2011 & 0.1367 & 0.3899 & 1.6561 \\
2012 & 0.1470 & 0.1378 & 0.2457 \\
2013 & 0.0361 & 0.2482 & 0.0845 \\
\hline
\end{tabular}

Tabel 2 menampilkan varian portfolio pada model indeks tunggal pada tiga sektor yang diteliti. Varian portofolio pada Model Indek Tunggal dapat dirumuskan sebagai berikut :

$$
\sigma p^{2}=\beta p . \sigma m^{2}+\left(\sum_{i=1}^{n} w i . \sigma e i\right)^{2}
$$

Return bebas resiko diasumsikan adalah 6.49 \% per tahun atau sama dengan 0.11 per bulan. Berdasarkan angka-angka tersebut diatas dapat dihitung kinerja portfolio dengan metode Sharpe sebagaimana pada Tabel 3.

Tabel 3. Hasil Pengukuran Kinerja dengan Metode Sharpe

\begin{tabular}{cccc}
\hline Tahun & $\begin{array}{c}\text { Sektor Makanan \& } \\
\text { Minuman }\end{array}$ & $\begin{array}{c}\text { Sektor Properti \& Real } \\
\text { Estate }\end{array}$ & $\begin{array}{c}\text { Sektor Minyak \& } \\
\text { Gas }\end{array}$ \\
\hline 2009 & 0.0126 & -0.0746 & 0.0551 \\
2010 & 0.0560 & 0.0157 & 0.4876 \\
2011 & 0.0603 & -0.0021 & 0.9717 \\
2012 & 0.0430 & 0.0160 & 0.3409 \\
2013 & 0.0331 & 0.0160 & 0.8906 \\
\hline \multicolumn{4}{c}{ Berdasarkan hasil perhitungan pada Tabel 3 memperlihatkan bahwa indeks }
\end{tabular}

Sharpe dari 2009 sampai dengan 2013 berada pada kisaran minimal -0.0021 hingga kisaran maksimal yaitu sebesar 0.9717 jika nilai indeks kinerja Sharpe / RVAR positif dan semakin besar maka kinerja portofolio semakin baik. Periode tahun 2009 sampai dengan tahun 2013, indeks Sharpe dari hasil perhitungan hampir 
secara merata disetiap tahunnya ada yang bernilai negatif. Hal ini menunjukkan bahwa dalam portofolio LQ 45 yang terbentuk tersebut kinerja Sharpe belum semuanya bernilai positif, seperti dalam perhitungan di atas ada 3 ( tiga) sub sektor portofolio saham dari 2009 sampai dengan 2013 selalu menunjukkan indeks kinerja Sharpe negatif antara lain sub sektor pertambangan minyak dan gas.

Dalam mengevaluasi kinerja portofolio saham dengan metode Treynor atau disebut sebagai Reward to Validaty Ratio (RVOR), menggunakan return rata-rata masa lalu sebagai expected return dan juga beta sebagai tolak ukur risiko. Beta menunjukkan besar kecilnya perubahan return suatu portofolio saham terhadap perubahan market return. Sebagaitolak ukur risiko investasi digunakan beta karena pada umumnya fluktuasi harga saham dipengaruhi oleh fluktuasi pasar. Beta dari hasil perhitungan antara periode tahun 2009 sampai dengan tahun 2013 (dapat dilihat pada tabel dibawah ini dan lampiran) Sub Sektor Makanan dan Minuman yaitu menunjukkan kisaran angka antara pada tahun 2009 sebesar 1.4809, tahun 2010 sebesar 0.8449, tahun 2011 sebesar 1.0815, tahun 2012 sebesar 0.5200, dan tahun 2013 sebesar 0.6683. Sedangkan untuk Sub Sektor Property dan Realestate yaitu menunjukkan kisaran angka antara pada tahun 2009 sebesar 0.1536, tahun 2010 sebesar 0.5850, tahun 2011 sebesar 0.0991, tahun 2012 sebesar 0.9306, dan tahun 2013 sebesar 0.3679. Serta untuk sub sektor Pertambangan dan Gas yaitu menunjukkan kisaran angka antara pada tahun 2009 sebesar 1.3828, tahun 2010 sebesar -11.7591 tahun 2011 sebesar -1.4248, tahun 2012 sebesar 1.9777, dan tahun 2013 sebesar 5.2407. Suatu sekuritas yang mempunyai beta $<1$ dikatakan berisiko lebih kecil dari portofolio pasar. Sebaliknya suatu sekuritas yang mempunyai nilai beta $>1$ dikatakan mempunyai risiko sistematik yang lebih besar dari risiko pasar. Adapun hasil perhitungan kinerja portofolio saham dari ke 3 (tiga) kelompok saham LQ 45 dengan metode Treynor dalam Tabel 4.

Hasil perhitungan pada Tabel 4 memperlihatkan bahwa indeks Treynor dari periode 2009 sampai dengan 2013 yaitu Sub Sektor Makanan dan Minuman yaitu menunjukkan kisaran angka antara pada tahun 2009 sebesar 0.5267, tahun 2010 sebesar 2.4026, tahun 2011 sebesar 2.0619, tahun 2012 sebesar 3.1731, dan tahun 2013 sebesar 0.9427. Sedangkan untuk Sub Sektor Property dan Realestate yaitu 
menunjukkan kisaran angka antara pada tahun 2009 sebesar -33.9844, tahun 2010 sebesar 1.3333, tahun 2011 sebesar -1.3118 , tahun 2012 sebesar 0.3653 , dan tahun 2013 sebesar 2.1745. Serta untuk sub sektor Pertambangan dan Gas yaitu menunjukkan kisaran angka antara pada tahun 2009 sebesar 2.5383, tahun 2010 sebesar -8.0754 tahun 2011 sebesar -87.7667, tahun 2012 sebesar 8.5453, dan tahun 2013 sebesar 4.9402. Jika nilai RVOL/Treynor positif dan semakin besar maka kinerja semakin baik. Periode tahun 2009 sampai dengan 2013, indeks Treynor dari hasil perhitungan hampir merata di setiap tahunnya positif hal ini menunjukkan bahwa portofolio LQ 45 yang terbentuk tersebut kinerja Treynor semuanya bernilai positif, seperti dalam perhitungan diatas, menunjukkan dari tahun 2009 sampai dengan tahun 2013 ke 3 (tiga) sub sektor tersebut selalu menunjukkan indeks yang antara lain: Sub Sektor Makanan dan Minuman, Sub Sektor Property dan Realestate serta Sub Sektor Pertambangan Minyak dan Gas. Hasil dari perhitungan indeks Treynor sama dengan hasil indek Sharpe, yang memunculkan ke 3 (tiga) kelompok saham tersebut bernilai positif.

Tabel 4. Tingkat Pengembalian Tahunan dengan Metode Treynor

\begin{tabular}{cccc}
\hline Tahun & $\begin{array}{c}\text { Sektor Makanan \& } \\
\text { Minuman }\end{array}$ & $\begin{array}{c}\text { Sektor Properti \& Real } \\
\text { Estate }\end{array}$ & $\begin{array}{c}\text { Sektor Minyak \& } \\
\text { Gas }\end{array}$ \\
\hline 2009 & 0.5267 & -33.9844 & 2.5383 \\
2010 & 2.4026 & 1.3333 & -8.0754 \\
2011 & 2.0619 & -1.3118 & -87.7667 \\
2012 & 3.1731 & 0.3653 & 8.5453 \\
2013 & 0.9427 & 2.1745 & 4.9402 \\
\hline
\end{tabular}

Untuk menganalisis metode Jensen membutuhkan data seperti avarage return, beta saham, minimum rate, dan risk free rate. Adapun hasil perhitungan kinerja saham dari ke-3 kelompok saham LQ 45 dengan metode Jensen dapat dilihat pada Tabel 5.

Berdasarkan Tabel 5, memperlihatkan bahwa indeks Jensen dari periode 2009 sampai dengan 2013 yaitu Sub Sektor Makanan dan Minuman yaitu menunjukkan kisaran angka antara pada tahun 2009 sebesar 0.9115, tahun 2010 sebesar 2.1050, tahun 2011 sebesar 2.3260, tahun 2012 sebesar 1.6962, dan tahun 2013 sebesar 0.6893. Sedangkan untuk Sub Sektor Property dan Realestate yaitu menunjukkan kisaran angka antara pada tahun 2009 sebesar -5.2063, tahun 2010 
sebesar 0.8319, tahun 2011 sebesar -0.1212, tahun 2012 sebesar 0.4226, dan tahun 2013 sebesar 0.1126. Serta untuk sub sektor Pertambangan dan Gas yaitu menunjukkan kisaran angka antara pada tahun 2009 sebesar 3.6327, tahun 2010 sebesar 96.0042 tahun 2011 sebesar 125.1765, tahun 2012 sebesar 17.0756, dan tahun 2013 sebesar 26.3553. Jika nilai Alpha Jensen yang tertinggi dan signifikan merupakan portofolio yang terbaik dari portofolio yang ada. Alpha bernilai positif, berarti manajer keuangan menghasilkan kinerja yang lebih baik dari indek pasar, sedangkan nilai negatif, berarti manajer keuangan memiliki kinerja yang lebih rendah dari pada indek pasar. Periode tahun 2009 sampai dengan 2013, indek Jensen dari hasil perhitungan hampir secara merata di setiap tahunnya bernilai positif. Hal ini menunjukkan bahwa dalam portofolio LQ 45 yang terbentuk tersebut kinerja Jensen belum semuanya bernilai positif, seperti dalam perhitungan diatas ke 3 (tiga) sub sektor kelompok saham tersebut dari tahun 2009 sampai dengan tahun 2013 selalu menunjukkan indeks kinerja positif. Hasil dari perhitungan indeks Jensen sama dengan hasil perhitungan indeks Sharpe dan indeks Traynor, yang juga memunculkan kelompok saham sub sektor pertambangan minyak dan gas yang paling banyak bernilai tinggi.

Penggunaan ketiga metode pengukuran kinerja berbasis risiko ini terlihat memiliki konsistensi antar satu metode dengan metode lainnya, hal ini serupa dengan hasil penelitian yang dilakukan oleh Yunan dan Rahmasari (2015); Rofiq dan Sutrisno; Lestari (2015). Hal berbeda ditemui oleh Juwenah dan Hidayat (2017), dimana terdapat beberapa kinerja dari saham syariah tidak dapat diambil keputusan pada saat penggunaan metode Jensen.

Tabel 5. Tingkat Pengembalian Tahunan dengan Metode Jensen

\begin{tabular}{cccc}
\hline Tahun & $\begin{array}{c}\text { Sektor Makanan \& } \\
\text { Minuman }\end{array}$ & $\begin{array}{c}\text { Sektor Properti \& Real } \\
\text { Estate }\end{array}$ & $\begin{array}{c}\text { Sektor Minyak \& } \\
\text { Gas }\end{array}$ \\
\hline 2009 & 0.9115 & -5.2063 & 3.6327 \\
2010 & 2.1050 & 0.8319 & 96.0042 \\
2011 & 2.3260 & -0.1212 & 125.1765 \\
2012 & 1.6962 & 0.4226 & 17.0756 \\
2013 & 0.6893 & 1.1126 & 26.3553 \\
\hline
\end{tabular}

Investor yang rasional akan memilih portofolio yang efisien, karena merupakan portofolio yang dibentuk dengan mengoptimalkan satu dari dua 
dimensi, yaitu dengan return ekspektasi atau return portofolio. Portofolio yang efisien adalah portofolio yang memberikan return ekspektasi terbesar dengan tingkat risiko yang sudah pasti atau portofolio yang mengandung risiko terkecil dengan tingkat return ekspektasi yang sudah pasti (Jogiyanto, 2003).

Portofolio optimal merupakan sesuatu yang unik atas investasi pada aset berisiko. Kemampuan untuk mengestimasikan tingkat pengembalian saham merupakan hal yang sangat penting dan diperlukan untuk investasi saham. Penyusunan portfolio dapat pula dilakukan dengan menggunakan data envelopment analysis (Fuad dan Agustanto, 2016). Selain itu, Simforianus dan Hutagaol (2008) mencoba melakukan pengujian analisis kinerja dana saham dengan menambahan metode raw return dan Sortino. Perusahaan yang terdaftar pada pasar modal harus mampu meningkatkan kinerja keuangannya, hal ini bertujuan untuk meningkatkan tingkat pengembalian saham (Rahmawati, 2017).

\section{SIMPULAN}

Setelah melakukan analisis terhadap hasil penelitian telah dijelaskan pada bab sebelumnya, maka dapat ditarik kesimpulan yaitu Indek kinerja Sharpe, Traynor dan Jensen menunjukkan 3 kelompok saham LQ 45 dari tahun 2009 sampai dengan tahun 2013 yang selalu menunjukkan indeks kinerja bernilai positif yaitu: Sub Sektor Makanan dan Minuman, Sub Sektor Property dan Realestate serta Sub Sektor Pertambangan Minyak dan Gas. Kelompok saham tersebut yang menunjukkan kinerja yang tertinggi yaitu kelompok saham Sub Sektor Pertambangan Minyak dan Gas, sebanding dengan risikonya juga sangat tinggi. Selain itu, Pengukuran kinerja portofolio dengan metode Sharpe, Treynor maupun Jensen akan memiliki karakteristik angka indeks yang beda tipis satu sama lainnya sehingga dapat dibandingkan secara logis. Hasil penelitian ini menunjukkan bahwa seiring dengan tingginya tingkat risiko, maka potensi untuk mendapatkan keuntungan yang lebih tinggi akan semakin besar.

Portofolio yang dibentuk tidak terbatas pada saham-saham LQ 45 saja tetapi dapat menggunakan saham-saham yang lain seperti saham individu dan saham sektoral yang lain. Sebaiknya kinerja yang telah ada dipertahankan dan lebih ditingkatkan sehingga misi untuk mengembangkan sumber-sumber energi 
potensial menjadi portofolio investasi yang menguntungkan terus berlanjut.

\section{PUSTAKA ACUAN}

Fuad, M. \& H. Agustanto. (2016). Analisis Penyusunan Portfolio dengan Menggunakan Metode Data Envelopment Analysis. Fokus Manajerial. Vol. 14 (2): 157-172.

Jogiyanto. (2003). Analisis Investasi dan Teori Portofolio. Yogyakarta: Gadjah Mada Press.

Juwenah \& F. Hidayat. (2017). Analisis Kinerja Saham Syariah Sektor Pertanian dengan Menggunakan Metode Sharpe, Treynor, dan Jensen. JRKA. Vol 3 (1): 41-52.

Lestari, W.R. (2015) Kinerja Reksadana Syariah dan Reksadana Konvensional. Jurnal Magister Manajemen. Vol. 1 (1): 116-118.

Markowitz, H. (1952). Portofolio Selection. Journal of Finance. Vol 7 (1): 77-91.

Markowitz, H. (1999). The Early History of Portofolio Theory: 1600-1960. Financial Analysis Journal. July-August: 5-16.

Mudasetia, H. (1995). Analisis Penentuan Saham yang akan dibeli: Suatu Tinjauan Umum. Kajian Bisnis. No. 6 September.

Rahmawati, A. (2017). Kinerja Keuangan dan Tingkat Pengembalian Saham: Studi Pada Perusahaan Asuransi di Bursa Efek Indonesia. Esensi: Jurnal Bisnis dan Manajemen. Vol. 7 (1): 1-14.

Rofiq, A. \& B.H. Santoso. (2015). Analisis Kinerja Reksa Dana dengan Menggunakan Model Sharpe, Treynor, dan Jensen. Jurnal Ilmu dan Riset Manajemen. Vol 4 (7): $1-20$.

Simforianus \& Y. Hutagaol. (2008). Analisis Kinerja Reksa Dana dengan Metode Raw Return, Sharpe, Treynor, Jensen, dan Sortino. Journal of Applied Finance and Accounting. Vol. 1 (1): 193-226.

Sutrisno, B. (2017). Hubungan Volatilitas dan Volume Perdagangan di Bursa Efek Indonesia. Esensi: Jurnal Bisnis dan Manajemen. Vol. 7 (1): 15-26.

Usman, B. (2016) The Phenomenon of Bearish and Bulish in The Indonesian Stock Exchange. Esensi: Jurnal Bisnis dan Manajemen. Vol. 6 (2): 181-198. 
Yunan, Z.Y. \& M. Rahmasari. (2015). Measurement of Shariah Stock Performance Using Risk Adjusted Performance. Al-Iqtishad: Jurnal Ilmu Ekonomi Syariah: Journal of Islamic Economics. Vol. 7 (1): 127-140.

Zubir, Z. (2011). Manajemen Portofolio: Penerapannya dalam Investasi Saham. Jakarta: Salemba Empat. 